\title{
Computerized rheometric method for studying rennet coagulation of milk
}

\author{
J. KOROLCZUK*, J.L. MAUBOIS*, R. CARDENAS*, \\ G. GROSCLAUDE** \\ * INRA, Laboratoire de Recherches de Technologie laitière \\ 65 , rue de Saint-Brieuc - 35042 Rennes cedex, France \\ ** SERT (INRA), chemin de la Géraudière - 44072 Nantes cedex, France
}

\section{Summary}

A dynamic viscometer coupled with a microcomputer was used to follow the changes of rheological properties of rennet gelifying milk during period of time up to $2000 \mathrm{~s}$ with automatic recording of time, stress and strain every $0.5 \mathrm{~s}$. SCOTT-BLAIR and BURNETT (1958) and DOUILLARD (1973) mathematical models were used to calculate the gelification time ( $t$ gel), final gel rigidity $\left(\mathrm{G}_{00}\right)$ and the constant $T_{1}$ representing the time between the gelification point and point when the relative rigidity $\mathrm{Gt} / \mathrm{G}_{00}$ reaches 0.1 .

From analyzed experiments, it is shown that the relative reciprocal coagulation time (ratio : $t$ gel at $\mathrm{pH} 6.6 / \mathrm{t}$ gel at $\mathrm{pH} \mathrm{x}$ ) depended linearely on $\mathrm{pH}$ of milk (for the $\mathrm{pH}$ range between 6.36 and 6.75 ) and on amount of added calcium. Coagulation time and constant $\left(T_{1}\right)$ evaluated from the results of phase angle changes were respectively $7 \%$ shorter and 4 times smaller than the ones evaluated from the apparent viscosity evolution. The real part $\left(n^{\prime}\right)$ of complex viscosity was changing during coagulation process from $10^{\circ}$ to $10^{4} \mathrm{mPas}$, while storage ( $\left.\mathrm{G}^{\prime}\right)$ modulus was increasing from $10^{-2}$ to $10^{4} \mathrm{mPa}$. Relaxation time for coagulated milk was $10^{-1}$ against $10^{2} \mathrm{~s}$ for original milk. Final apparent viscosity of gels (na) was between 1 and $2 \times 10^{5} \mathrm{mPas}$ depending on $\mathrm{pH}$ and calcium concentration.

Keys words : Milk - Coagulation - Rennet - Viscosity - Rheological behavior Calcium - pH.

\section{Résumé}

Méthode rhéométrique informatisée d'étude de la coagulation du lait par la présure

Un viscosimètre, de type Couette, raccordé à un micro-ordinateur, était utilisé, en régime harmonique, pour suivre les changements de propriétés rhéologiques intervenant pendant la gélification du lait, sous l'action de la présure. Les modèles mathématiques de SCOTT-BlAIR et BURNETT (1958) et DOUILLARD (1973) étaient utilisés pour déterminer le temps de gélification ( $t$ gel), la rigidité finale $\left(G_{00}\right)$ et la constante $\left(\mathrm{T}_{1}\right)$ qui représente l'intervalle de temps entre le point de gélification et le moment où la rigidité relative $\left(\mathrm{Gt} / \mathrm{G}_{00}\right)$ atteint la valeur 0,1 .

Les expérimentations réalisées ont mis en évidence des relations linéaires entre le temps de gélification relative (rapport : t gel à $\mathrm{pH} 6,6 / \mathrm{t}$ gel à $\mathrm{pH} \mathrm{x}$ ) avec le $\mathrm{pH}$ du lait (dans la gamme de $\mathrm{pH}$ comprise entre 6,75 et 6,36 ) et la quantité ajoutée d'ions calcium (entre 0 et $20 \mathrm{mM}$ de $\mathrm{CaCl}_{2}$ ). Le temps de gélification et la constante $\mathrm{T}_{1}$, évalués en prenant en considération les variations de l'angle de déphasage étaient

\footnotetext{
- Correspondence should be sent at this address.
} 
respectivement environ $7 \%$ plus courts et 4 fois plus faibles que ces mêmes valeurs évaluées en se basant sur les variations de viscosité apparente.

La partie réelle $\left(n^{\prime}\right)$ de la viscosité complexe évoluait pendant la gélification de $10^{0}$ à $10^{4} \mathrm{mPas}$ alors que le module de rigidité $\left(\mathrm{G}^{\prime}\right)$ croissait de $10^{-2}$ à $10^{4} \mathrm{mPa}$. Le temps de relaxation pour le lait gélifié était d'environ $10^{-1} \mathrm{~s}$ contre $10^{2} \mathrm{~s}$ pour le lait initial. La viscosité apparente finale des laits gélifiés était comprise entre 1 et $2 \times 10^{5} \mathrm{mPas}$ selon le $\mathrm{pH}$ et la concentration en ions $\mathrm{Ca}$ ajoutés.

Mots clés : Lait - Coagulation - Présure - Viscosité - Comportement rhéologique Calcium - $\mathrm{pH}$.

\section{Introduction}

Changes of physical properties of milk during rennet coagulation have been studied by many authors. ScotT-BLAIR and BURNETT (1958 a, 1958 b, 1959, 1963) used an U-tube gelometer to study the viscoelastic properties of renneted gelifying milk. TARODO DE LA FUENTE and FrENTZ (1966) and TARODO DE LA FUENTE et al. (1969) used the thromboelastograph to follow rennet coagulation of milk and syneresis of renneted milk gels. A torsiometer and thromboelastograph were used by TuszYNSKI et al. (1968) and TUSZYNSKI (1971) to study effets of $\mathrm{pH}$, calcium and sulphur-bond inhi. bitors on the rate of setting of renneted milk. Tsouli et al. (1975) applied conductimetry and PARKER and DALGLEISH (1977 a,b) used the light scattering method to detect early stages of rennet coagulation of milk. Culioli and SHERMAN (1978) used SCOTT-BLAIR and BURNETT (1958 a) U-tube gelometer to establish the rheological properties of gelifying milk and renneted milk gels.

Bachman et al. $(1978,1980)$ used an ultrasonic viscometer to measure milk clotting activity of proteolytic enzymes. ToKITA et al. $(1980,1981,1982 \mathrm{a}, \mathrm{b}, \mathrm{c})$ used a torsion pendulum apparatus to describe the dynamic mechanical properties of renneted milk gels. GARNOT et al. (1982) used a curd firmness tester described by KOWALCHYK and OLSON (1978) to evaluate effects to fat and protein contents of ultrafiltrated milks on rheological properties of rennet gels. RAMET et al. (1982) proposed an oscillating vertical sphere set up into an Instron universal testing machine used as a dynamic rheometer to follow enzymatic coagulation of milk. GERVAIS and VERMEIRE (1983) employed an improved version of BURNETT and SCOTT-BLAIR (1963) torsiometer to follow setting of renneted milk in cheese vat. BoHLIN et al. (1984) described a dynamic viscoelastometer used to tollow the evolution of viscoelstic properties of coagulatin milk.

The afore mentioned methods, if they allow to have a good idea of the evolution of physical characteristics of renneted milks, were carried out with analog devices of data collection. Such devices as plotting tracer whatever was their sensibility made difficult and approximate establishment of numbered relationships between the different factors involved in milk gelation. By using digital data collection and related processing devices, it becomes possible to realize and to deal with a large number of measurements and so, to obtain a highly better mathematical description of the 


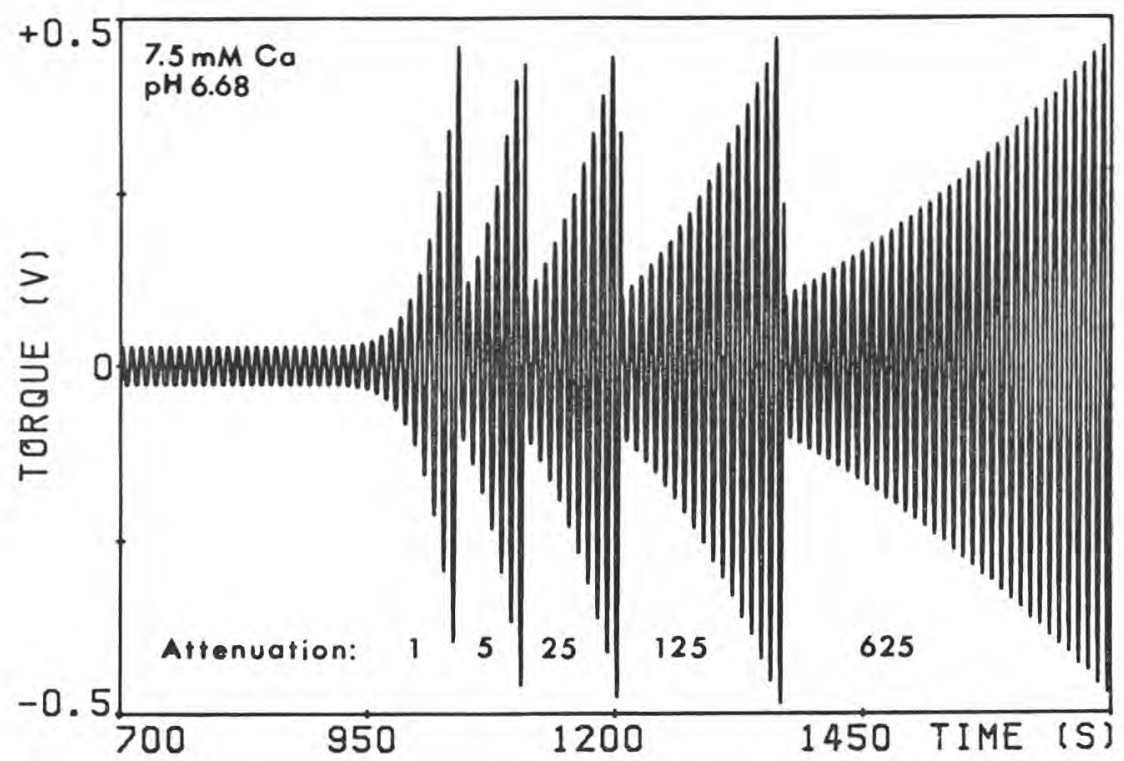

Fig. 1

Torque evolution during rennet coagulation of milk. Experimental conditions : rennet/milk protein $=1: 300 ;$ temperature $35^{\circ} \mathrm{C} ; \mathrm{pH} 6.68 ; 7.5 \mathrm{mM}$ of added calcium ions.

Evolution du couple pendant la coagulation du lait. Conditions expérimentales : présure/ protéines du lait $=1: 300$; température $35^{\circ} \mathrm{C} ; \mathrm{pH} 6,68 ; 7,5 \mathrm{mM}$ en ions calcium ajoutés par litre de lait.

phenomena which is the necessary first step before future automation of cheese vats.

The aim of this work was to apply the computerized dynamic viscometer described in our previous work (KoRolczuk et al. 1985) to follow changes of viscoelastic properties of rennet coagulating milk.

\section{Materials and methods}

Spray dried, low heat commercial skim milk powder was reconstituted in distilled water at room temperature $10 \% \mathrm{w} / \mathrm{w}$. Sodium azide (Merck, GFR) was added $(0.02 \% \mathrm{w} / \mathrm{v})$ as an antiseptic and calcium chloride (Merck, GFR) (up to $15 \mathrm{mM}$ ) to increase the level of soluble calcium ions, $\mathrm{pH}$ of this so-reconstituted milk was corrected with $0.5 \mathrm{M} \mathrm{NaOH}$ and the milk was then left for one hour at $35^{\circ} \mathrm{C}$, before rennet addition (commercial powder rennet from Hansen France dissolved in $0.02 \% \mathrm{NaN}_{3}$ ). Dry matter content of renneted milk was $9.1 \%$, protein $(\mathrm{N} \times 6.38)$ content was $3.41 \%$ and the proportion of milk protein to rennet was $300: 1$.

An oscillatory viscometer - Low Shear - 30 sinus (Contraves, Switzerland) connected to a microcomputer - Apple II plus (Apple Computer 


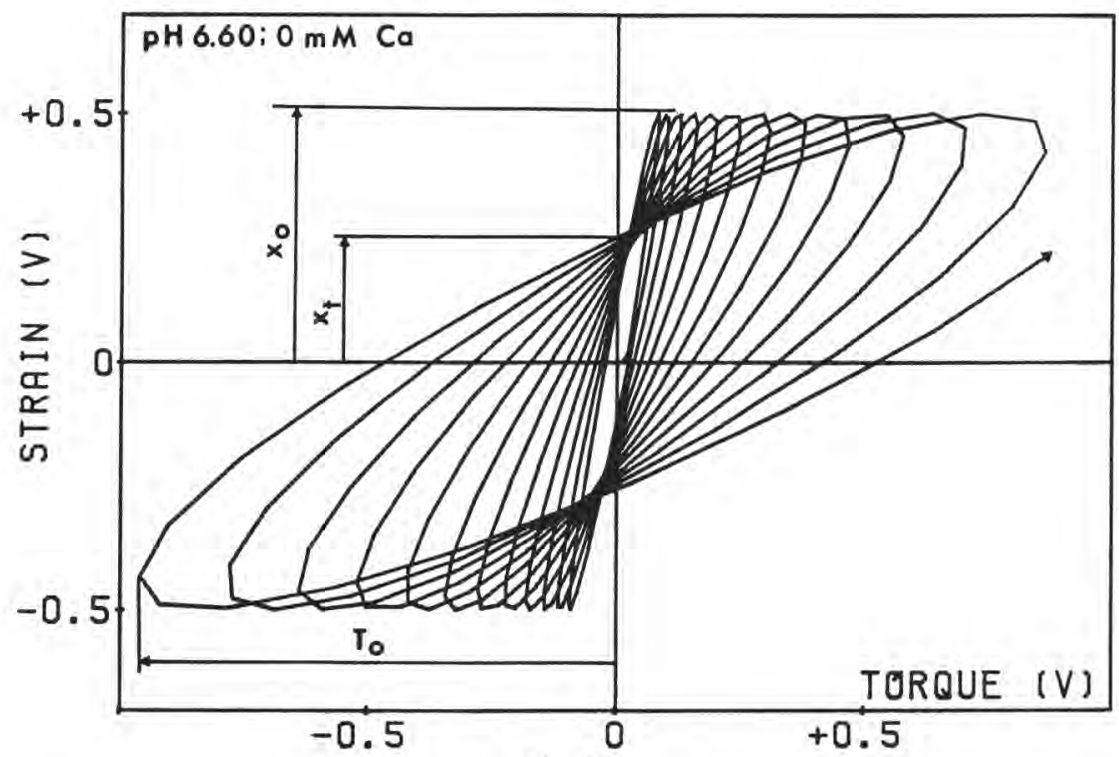

Fig. 2

Evolution of torque as a function of strain during the initial phase of rennet gelification of milk. Experimental conditions : rennet/milk proteins $=1: 300 ;$ temperature $35^{\circ} \mathrm{C}$; $p H 6.60 ;$ no calcium ions added. To torque; $X o=$ strain amplitude $; X t=$ strain value for the torque equal zero and the time equal $t$.

Evolution du couple en fonction de la vitesse de cisaillement pendant la phase initiale de la gélification du lait par la présure. Conditions expérimentales présure/protéines du lait $=1: 300$; température $35^{\circ} \mathrm{C} ; \mathrm{pH} 6,60$; sans calcium ajouté au lait. To $=$ couple en volts $; X o=$ amplitude de la vitesse de cisaillement en volts $; X t=$ valeur de la vitesse de cisaillement pour le couple égal zéro et le temps égal t.

Inc., U.S.A.) through the analog digital converter - $\mathrm{MAC}-4000$ (Analog Devices, U.S.A.) was used (KoRolczuK et al. (1985). Up to 4000 experimental readings of time, stress and strain were collected during one experiment lasting up to $2000 \mathrm{~s}$.

The frequency of the viscometer was set to $0.1 \mathrm{~Hz}$, the amplitude of the external cylinder movement was \pm 7.5 degrees. We used external cylinder with diameter of $12 \mathrm{~mm}$ and two internal cylinders : $11 \mathrm{~mm}$ for viscosities lower than 1 Pas or $3 \mathrm{~mm}$ for viscosities higher than 0.1 Pas. The viscometer was calibrated with a standard fluid having a viscosity of $5000 \mathrm{mPas}$ at $20^{\circ} \mathrm{C}$ (VEB MLV, GDR). During coagulation of milk, the temperature was kept constant $35 \pm 0.1^{\circ} \mathrm{C}$.

\section{Results and discussion}

As it is shown in figure 1, during the first phase of rennet coagulation process, the stress amplitude was practically constant. When polymerisation of casein micelles started, the stress amplitude first increased rapidly, then 


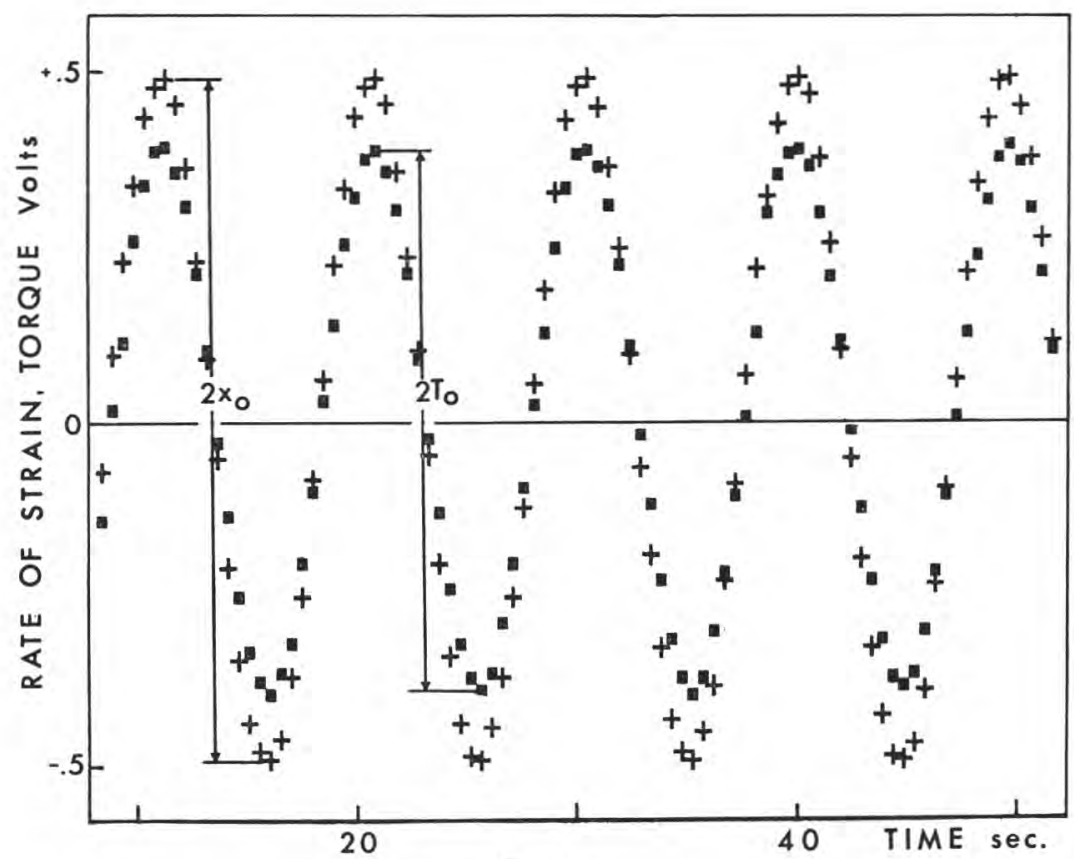

Fig. 3

Rate of strain $(+++)$ and torque ( $\mathbf{m})$ evolution during the initial period of rennet coagulation of milk. Experimental conditions are the same as in the figure 2. Xo = strain amplitude $;$ To $=$ torque amplitude.

Evolution $d u$ gradient de vitesse $(+++)$ et du couple (1. a) pendant la période initiale de la coagulation du lait par la présure. Les conditions expérimentales sont les mêmes que dans la figure 2. Xo = amplitude du gradient de vitesse; To = amplitude du couple.

slowed down. The evolution of stress amplitude in the figure 1 was similar to that recorded by the thromboelastograph (TARODO DE LA FUENTE and FRENTZ, 1966 ; Tuszynski et al., 1968 ; TARodo de la Fuente and Alais, 1969).

Of course, when using a computerized dynamic viscometer instead of the thromboelastograph it is possible not only to detect the gelification time and eventually the final rigidity expressed in arbitrary units, but also to establish the rheological properties, expressed in physical units, for any stage of milk gelification. If stress is represented as a function of strain (fig. 2) then the increase of stress takes form of an evolving ellips. Phase angle ( $\delta$ ) between the stress and the strain could be calculated from the equation :

$$
\delta=\arccos \frac{\mathrm{Xt}}{\mathrm{Xo}}
$$

where : $\mathrm{Xt}$ - strain value for torque equal to zero,

Xo - maximal strain value.

This relationship allows to calculate the phase angle with quite a good precision even when using only $\mathrm{X}, \mathrm{Y}$ recorder. As we used a computer 


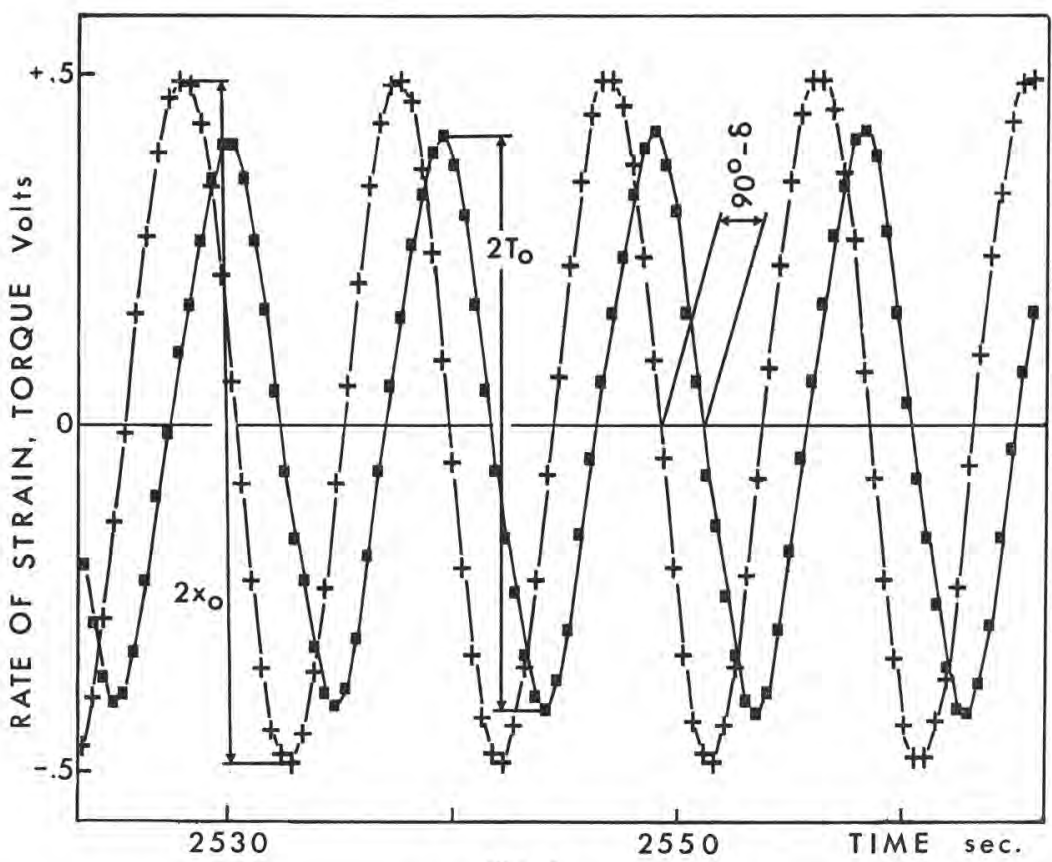

Fig. 4

Rate of strain $(+++)$ and torque ( $\mathbf{m}$ ) evolution during the final period of rennet coagulation of milk. Experimental conditions are the same as in the figure 2. Xo = rate of strain amplitude $;$ To $=$ torque amplitude $; \delta=$ phase angle.

Evolution du gradient de vitesse $(+++)$ et du couple (1 a) pendant la période finale de la coagulation du lait par la présure. Les conditions expérimentales sont les mêmes que dans la figure 2. Xo = amplitude du gradient de vitesse; To = amplitude du couple; $\delta=$ angle de déphasage.

which recorded every $0.49 \pm 0.001 \mathrm{~s}$ the values of strain, torque and time with precision better than $0.2 \%$, the phase angle was computed directly as described in our previous work (KoROLCZuK et al., 1985).

As it could be seen in the figures 3 and 4 , the used equipment enabled us to realize 20 acquisitions of strain and torque per each cycle lasting about $10 \mathrm{~s}$. This gives good enough reproducibility of the evolution of the strain and the torque as function of time.

The torque plotted as a function of strain (fig. 5 and 6) gives an elliptic curve, with the phase angle equal to $84^{\circ}$ for the milk just mixed with the rennet to about $20^{\circ}$ for renneted milk gel.

Theoretically the strain evolution as a function of time for the used equipment, is a sinusoidal function :

$$
X t=X_{0} \cdot \sin \alpha
$$

where: $\mathrm{Xt}$ - strain as a function of time.

Xo - maximal strain value,

$\alpha$ - angle measured at the beginning of the cycle. 


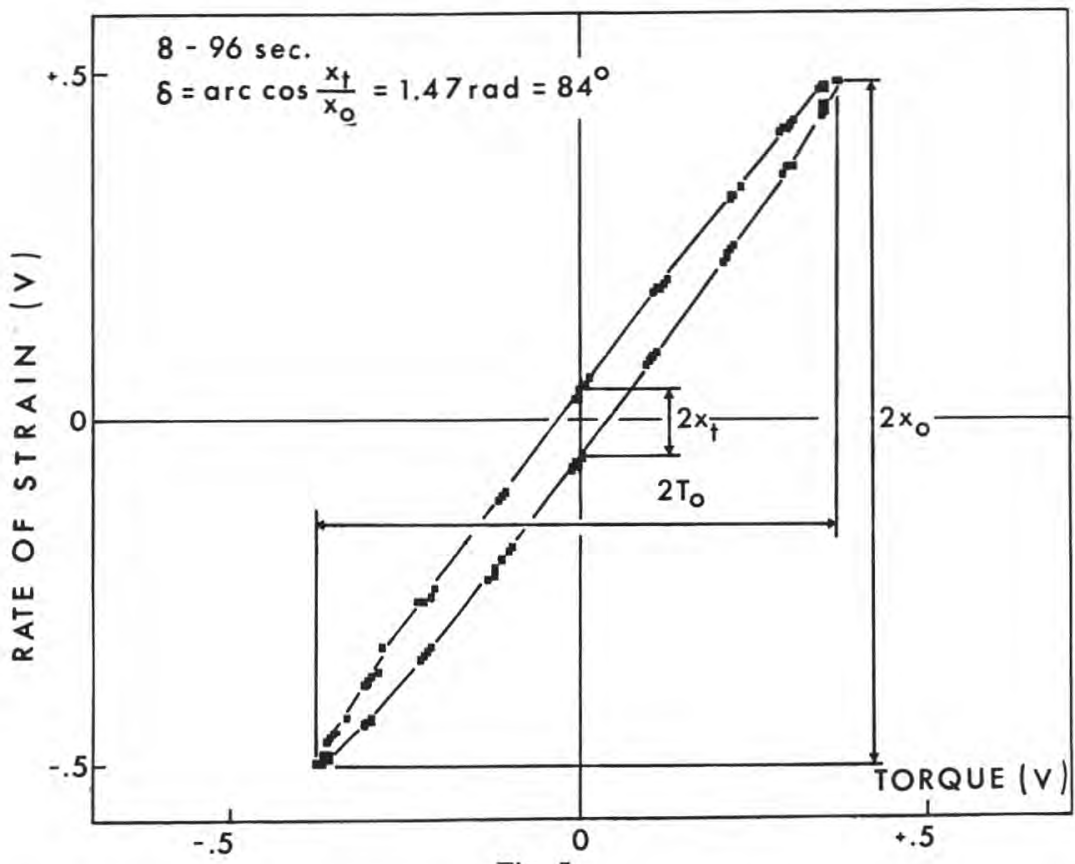

Fig. 5

Rate of strain and torque interrelation for the initial period of rennet coagulation of milk ( $8-96$ sec. after addition of rennet). Experimental conditions are the same as in the figure 2. $X o=$ rate of strain amplitude $; X t=$ rate of strain amplitude for the torque equal zero and the time equal $t ;$ To $=$ torque amplitude.

Rapport entre le gradient de vitesse et le couple pendant la phase initiale de la coagulation du lait par la présure ( $896 \mathrm{sec}$. après l'addition de la présure).

If Xo is plotted against angle ( $\alpha$ ) as in the figure 7 then the calculated values for each angle should give two straight parallel lines to the central line representing strain equal to zero. As it could be seen in figure 7 reasonably good linearity is obtained for the angle range between about 0.5 and 2.5 radians which corresponds to the rate of strain range between half and the maximum value. Practically the maximal rate of strain for each cycle can be estimated for $\alpha=\pi / 2$, as an average of Xo values situated in the angle range between 1-2 radians. The coefficient of variation in this case was about $0.2 \%$.

The same approach was used to check the "linearity " of the torque evolution. As it is shown in the figure 8 , at the very beginning of the rennet coagulation process, the milk behaved as an almost purely newtonian body. On the other hand, the renneted milk gel behaved quite differently. The stress is a non-linear function of the rate of strain. From the record of twenty values of strain and torque per each cycle it is possible to fit the results into a mathematical model representing the evolution of stress as a function of strain and time (fig. 9). But for the continuation of this study the maximum of the torque amplitude was choosen as the value calculated 


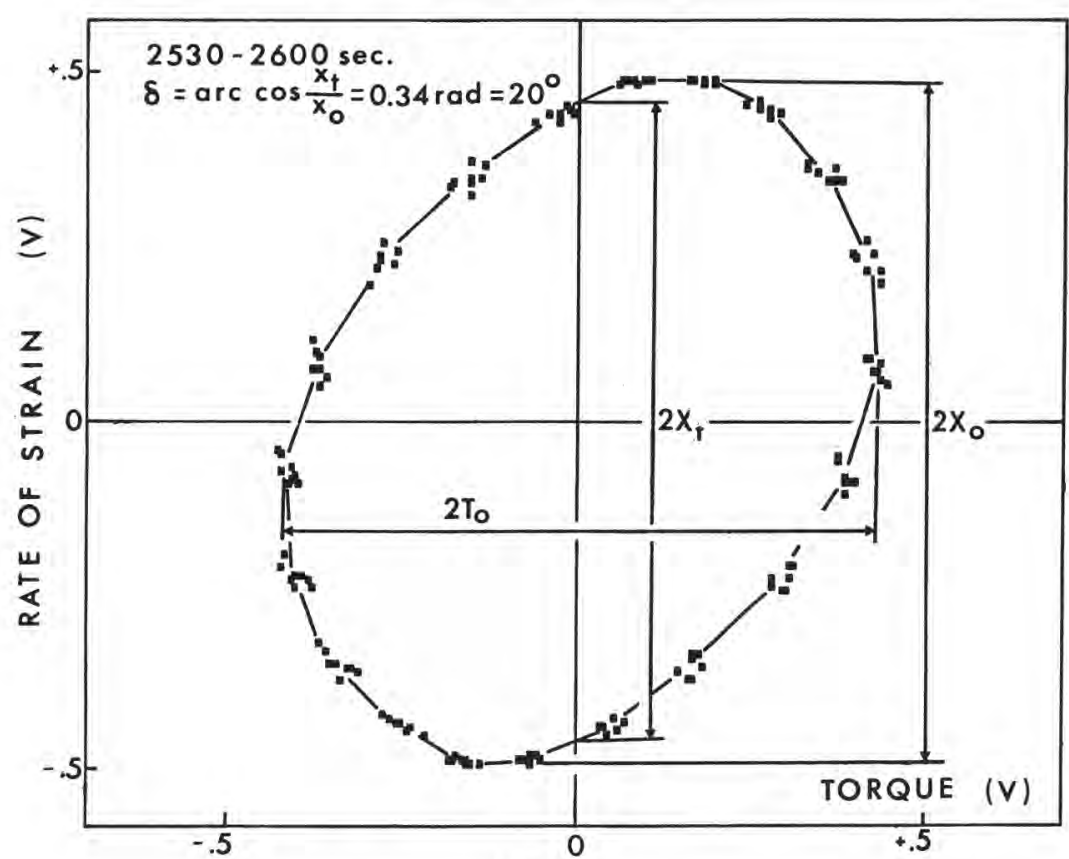

Fig. 6

Rate of strain and torque interrelation for the final period of rennet coagulation of milk (2530-2.600 sec. after addition of rennet). Experimental conditions are the same as in the figure 2. $X o=$ rate of strain amplitude $: X t=$ rate of strain amplitude for the torque equal zero and the time equal $t$; To = torque amplitude.

Relations entre le gradient de vitesse et le couple pendant la phase finale de la coagulation du lait par la présure (2530-2600) sec. après l'addition de la présure. Les conditions expérimentales sont les mêmes que dans la figure 2. Xo $=$ amplitude du gradient de vitesse ; $X t=$ amplitude du gradient de vitesse pour le couple égal zéro et le temps égal $t$; To $=$ amplitude du couple.

for the angle equal to $\pi / 2$, through the linear interpolation method, from the results situated within the angle range between 1 and 2 radians and that, separately for each half of sinusoidal cycle. Finally the calculated torque amplitude (To) for each cycle was the sum of the two " halves » of the absolute values of the torque amplitude for the first and the second half of each sinusoidal cycle. This gave one average value of torque amplitude every 10 seconds. As the stress is proportional to the torque amplitude and as the rate of strain is a function of frequency, so both of these values as well as the phase angle could be easily calculated from the data recorded during each experiment. From the knowledge of the torque amplitude (To), rate of strain (D) and the phase angle ( $\delta$ ) all viscoelastic functions could be calculated. Our analysis was limited to three basic functions :

- complex viscosity $\left(n^{*}\right)$;

- real part of complex viscosity ( $\left.n^{\prime}\right)$;

- storage or elasticity modulus $\left(\mathrm{G}^{\prime}\right)$. 


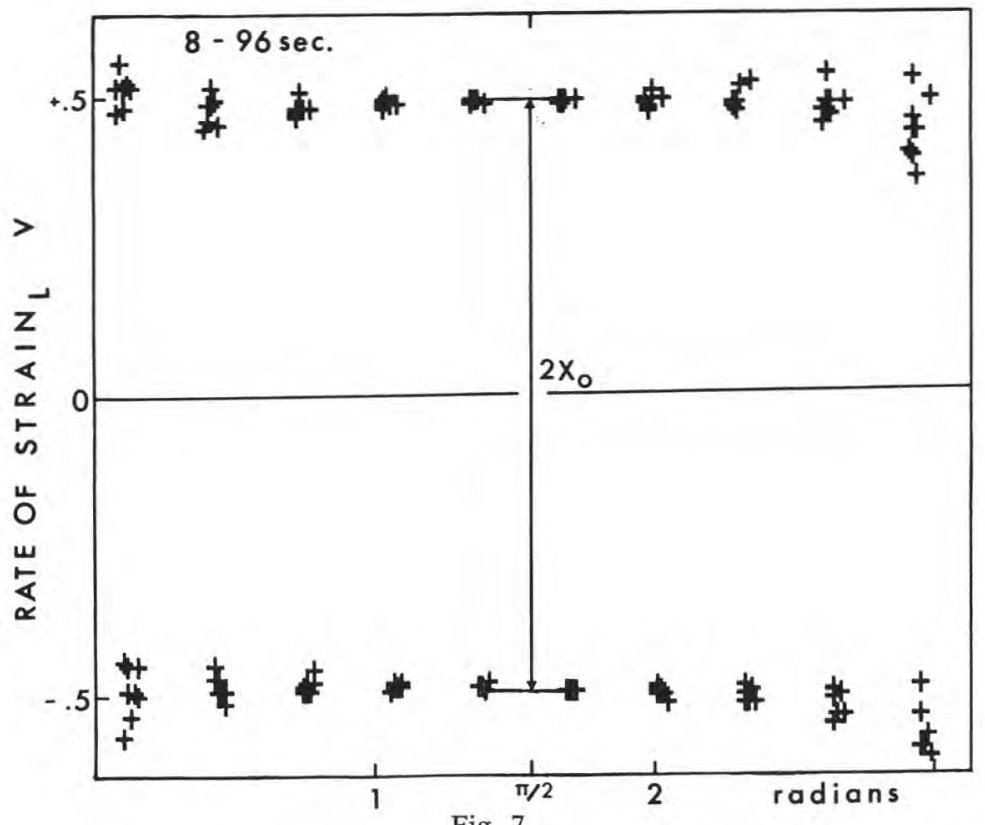

Fig. 7

Linearized rate of strain amplitude as a function of angle measured from the beginning of each sinusoidal half-cycle. Xo $=$ rate of strain amplitude for the angle equal $90^{\circ}$.

Gradient de vitesse linéarisée en fonction de l'angle mesuré du début de chaque demi-cycle sinusö̈dal.

During the enzymatic phase of rennet coagulation process, the evolution of each viscoelastic function is very slow and hardly detectible. When coagulation starts, the logarithms of complex viscosity, real part of complex viscosity, phase angle and storage modulus seemed to be inversely proportional to the time (fig. 10).

$$
\log F=\log F_{00}-\frac{T}{t}
$$

where: $F$ - the value of a viscoelastic function for the time $t$,

$\mathrm{F}_{00}$ - hypothetical value of viscoelastic function for the time $=00$,

$\mathrm{T}$ - time to reach $10 \%$ of $\mathrm{F}$.

The gelification time calculated from the evolution of each viscoelastic function to the initial value is not the same. In the example given in the figure 10, the gelification time estimated from the changes of phase angle was about $100 \mathrm{~s}$ shorter than the one evaluated from complex viscosity evolution. It seemed also that evolution of phase angle was much faster than changes of complex viscosity. The constant representing the time at which a viscoelastic function reached $10 \%$ of its hypothetical final value, was about 10 times higher for the complex viscosity (32220 s) than for the phase angle (3268 s). That leads to, in practical application, the phase 


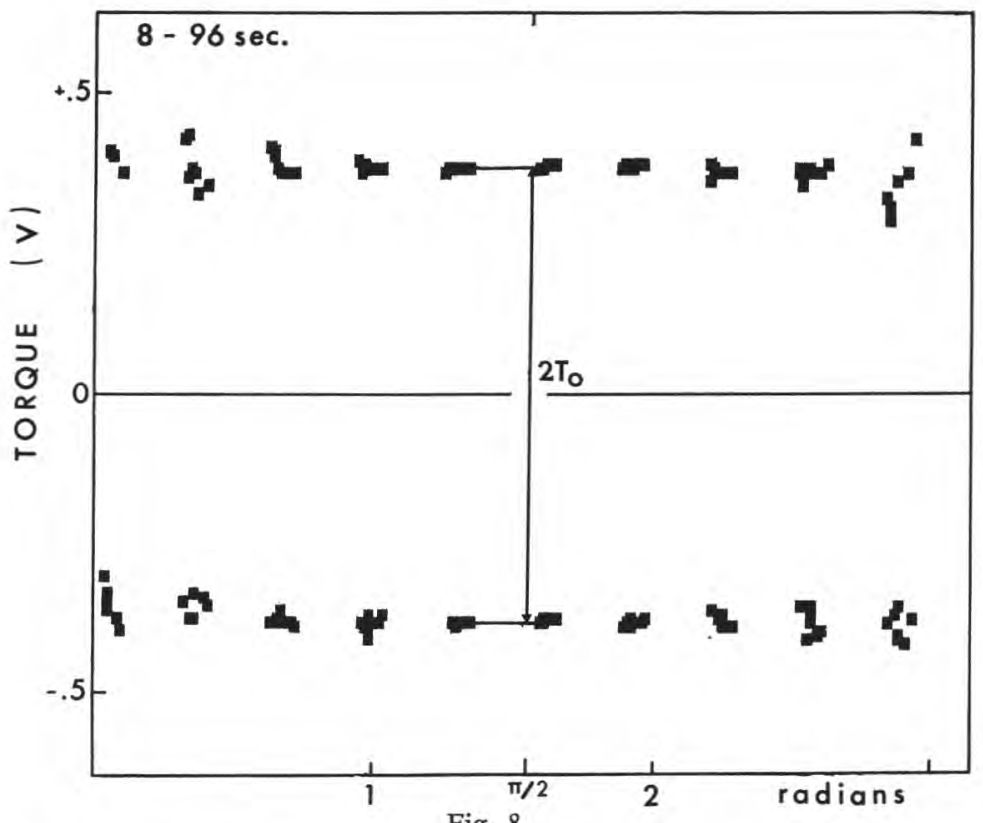

Fig. 8

Linearized torque amplitude as a function of angle measured from the beginning of each sinusoidal half-cycle, for the initial period of rennet coagulation of milk (8-96 sec., after addition of rennet). Experimental conditions are the same as in the figure 2. To = torque amplitude for the angle equal $90^{\circ}$.

Amplitude du couple linéarisée en fonction de l'angle mesuré du début de chaque demicycle sinusoïdal, pour la période initiale de la coagulation du lait par la présure (8-96 sec. après l'addition de la présure. Les conditions expérimentales sont les mêmes que dans la figure 2. To = amplitude du couple pour l'angle égale $90^{\circ}$.

angle evolution would be a better gelification detector than the complex viscosity evolution.

If equation (3) well describes the first parts of evolution of viscoelastic behavior of renneted milk gels, it is not the case for the last parts. The upper part of the "S curve " described by equation (3) did not agree with visual observations and direct measurements.

The last phase of rennet gelification of milk is better represented by the two mathematical models successively proposed by ScoTT-BLAIR and BuRNeTt (1958) and DouillaRd (1973) particularly the last one :

$$
\log \frac{\mathrm{F}_{00}-\mathrm{F}}{\mathrm{F}}=\frac{\mathrm{t}-\mathrm{t} \text { gel }}{\mathrm{T}_{1}}
$$

where : $\mathrm{t}$ gel $=$ gelification time.

As shown by figure 11 describing apparent viscosity evolution in function of time at $\mathrm{pH}$ 6.64. This model was used for the treatment of the data 


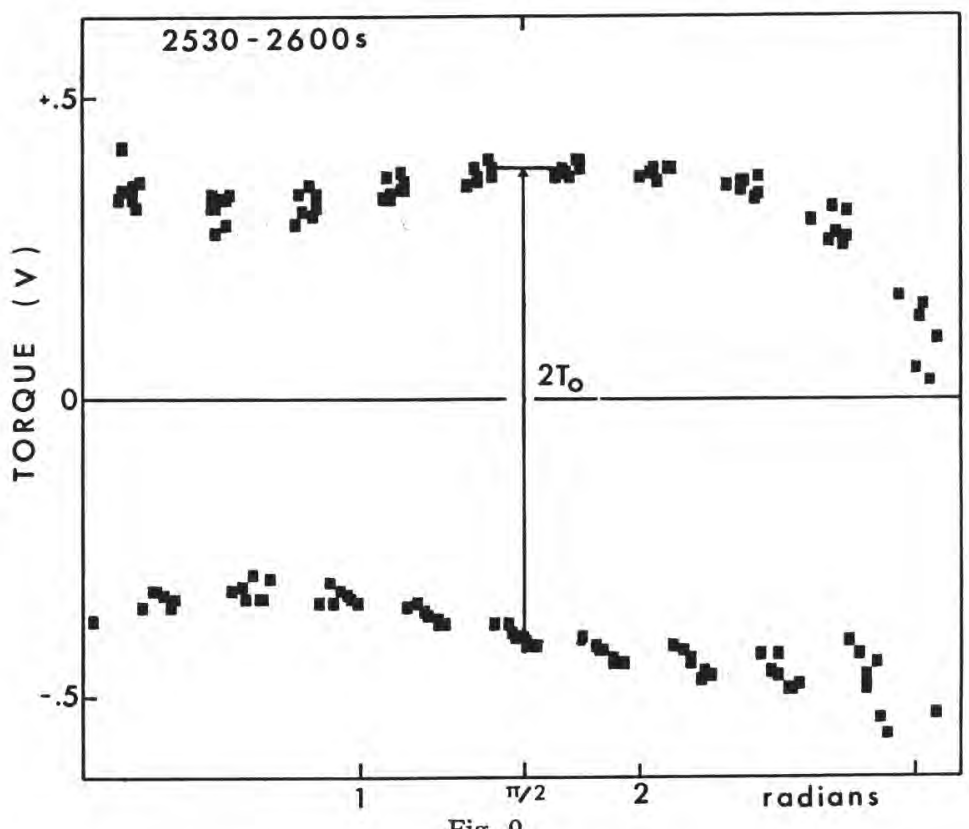

Fig. 9

Linearized torque amplitude as a function of angle measured from the beginning of each sinusoidal half-cycle, for the final period of rennet coagulation of milk (2530-2600 s after addition of rennet). Experimental conditions are the same as in the figure 2. To = torque amplitude for the angle equal $90^{\circ}$.

Amplitude du couple linéarisé en fonction de l'angle mesuré du début de chaque demicycle sinusoïdal, pour la période finale de la coagulation du lait par la présure (2530$2600 \mathrm{sec}$. après l'addition de la présure). Les conditions expérimentales sont les mêmes que dans la figure 2. To = amplitude du couple pour l'angle égal $90^{\circ}$.

related to the effect of $\mathrm{pH}$ variation and calcium addition because it was more simple to apply than the one previously proposed by the same authors :

$$
\log \frac{F}{F_{00}}=-\frac{T_{2}}{t-t \text { gel }}
$$

where : $\mathrm{T}$ is a constant representing the duration of time between the coagulation time and the time when $\mathrm{F}$ reaches $90 \%$.

Neither of these two models represents the whole process of rennet coagulation of milk (Scott-BlaIr and Oosthuizen, 1961 ; Scott-BlaIr and Burnett, 1963 ; Parker and Dalgleish, $1977 \mathrm{a}, \mathrm{b}$ ), but they describe quite well the evolution of rheological properties of gelifying milk (ТокітA et al., 1980, 1981, $1982 \mathrm{a}, \mathrm{b}, \mathrm{c}$; QVIST, 1982 ; Gervais and VermeIre, 1983) i.e. the formation and hardening of milk gels.

Mathematical treatment of all our experimental results as these represented in figure 11 shows that this good adjustment is only right when $\mathrm{F} / \mathrm{F}_{00}$ is in the 0.1-0.8 range. Outside this range, both models diverged but 


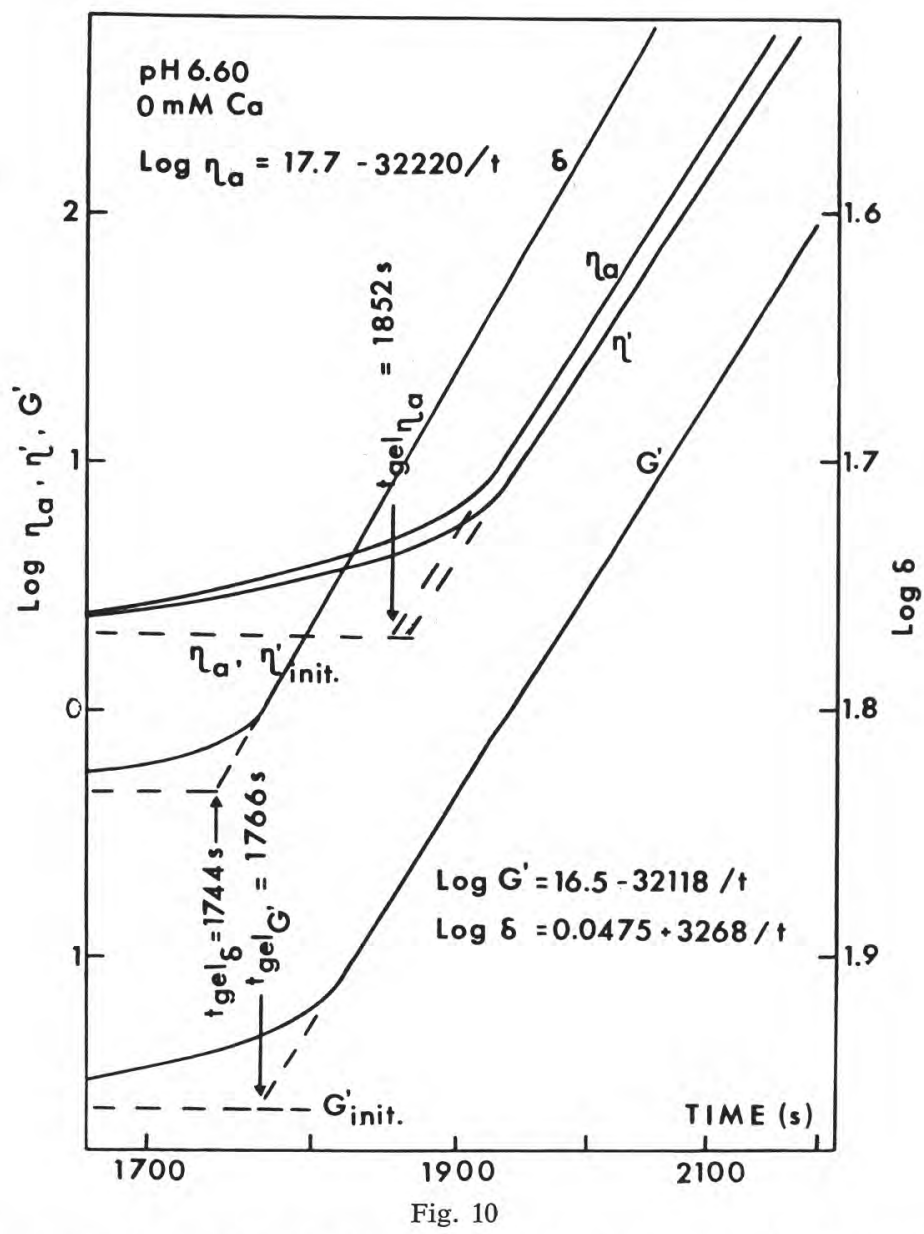

Relations between the logarithm of complex viscosity (na), real part of complex viscosity $\left(\eta^{\prime}\right)$, elasticity modulus $\left(G^{\prime}\right)$, phase angle $(\delta)$ and the reciprocal time.

Relations entre le logarithme de la viscosité apparente (na), la partie réelle de la viscosité complexe $\left(\eta^{\prime}\right)$, le module d'élasticité $\left(G^{\prime}\right)$, l'angle de déphasage ( $\left.\delta\right)$ et l'inverse du temps.

there are simple relationships between the used parameters :

- gelification time estimated from equation (5) represents 1.42 times gelification time estimated from equation (4);

- $F_{00}$ estimated from equation (4) does represent only $84 \%$ of $F_{00}$ estimated from equation (5) ;

- $\mathrm{T}_{1}$ is equal to $21.9 \mathrm{~T}_{2}$.

Above mentioned relationships can be used when results calculated by the two models are compared. 


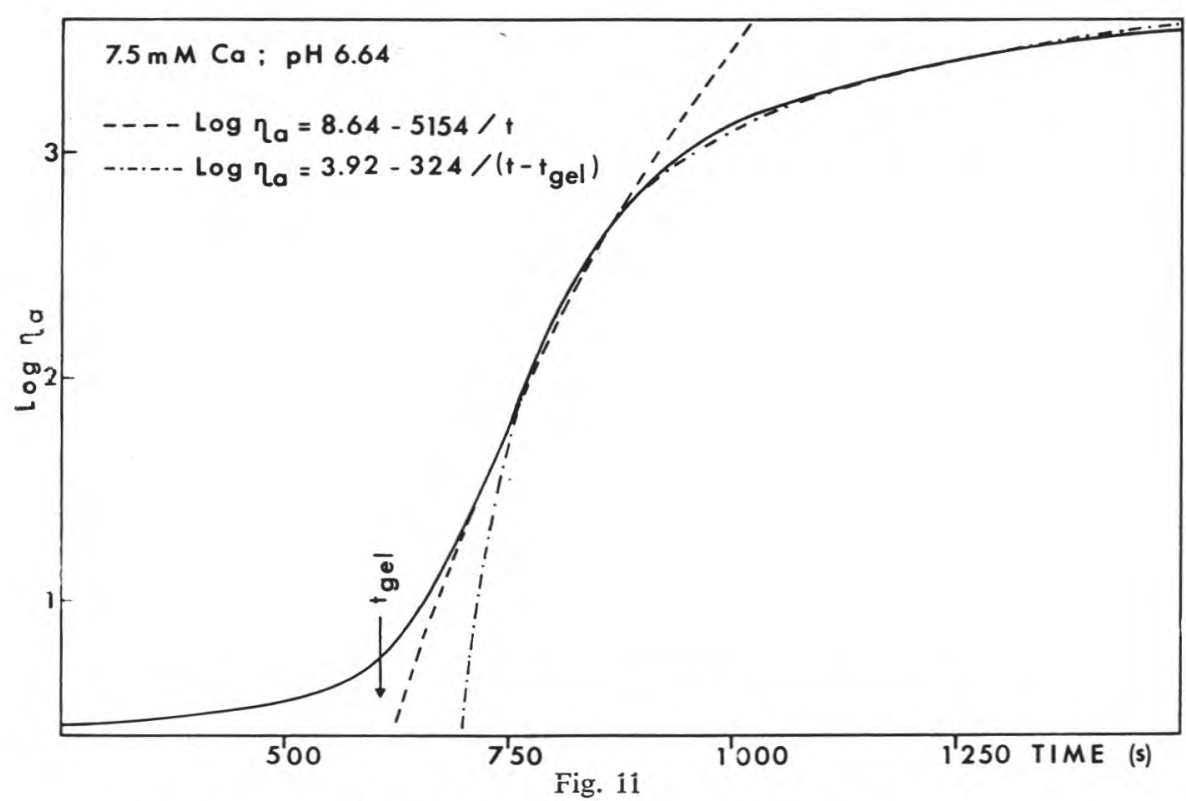

Apparent viscosity (na) evolution during rennet coagulation of milk and the representation of this process by the two mathematical models given in equation (4) and (5).

Evolution de la viscosité apparente (na) pendant la coagulation du lait et la représentation de ce processus par les deux modèles mathématiques donnés dans les équations (4) et (5).

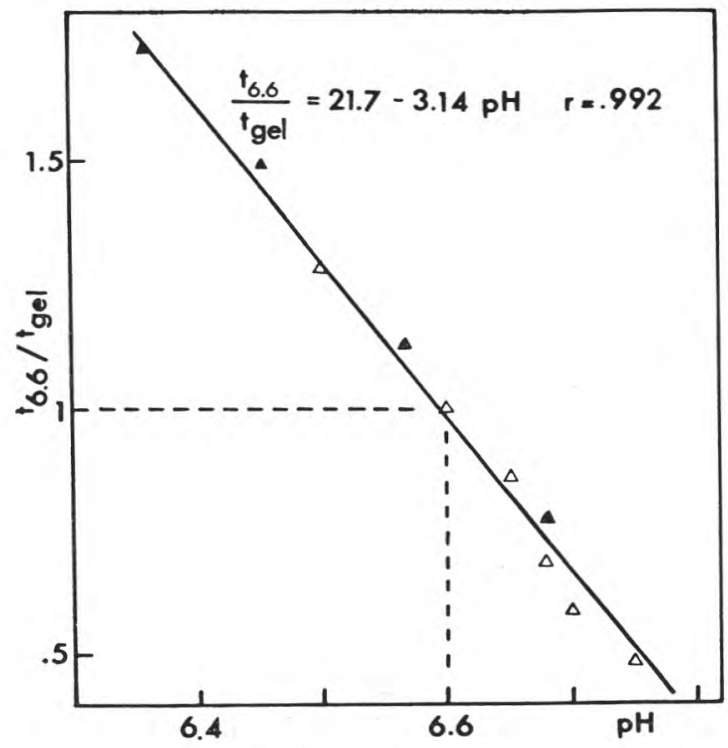

Fig. 12

Correlation between $p H$ and the rclative reciprocal coagulation time. The coagulation time at $p H 6.6$ was taken for unity : $\triangle \triangle=$ results of Fox (1969); $\mathbf{\Lambda}=$ results obtained in this work.

Corrélation entre $p H$ et l'inverse relative du temps de coagulation. Le temps de coagulation à $p H 6.6$ était pris pour une unité. $\Delta \Delta=$ résultats de Fox (1969); $\mathbf{\Delta} \mathbf{\Lambda}=$ résultats obtenus dans ce travail. 


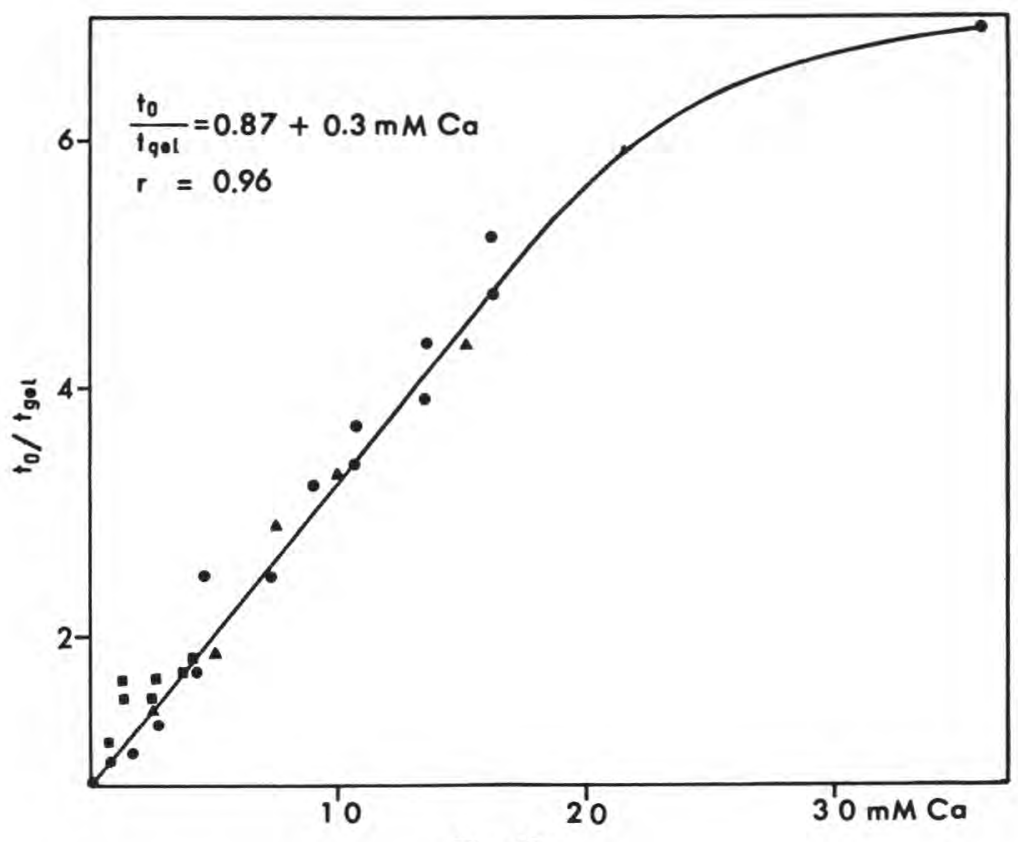

Fig. 13

Correlation between the amount of added calcium ions and the relative reciprocal gelification time. The gelification time for the milk without calcium added was taken for unity. $\bullet=$ results of TARODO DE LA FUENTE and FRENTZ $(1960) ; \quad=$ results of SCOTT-BLAIR and BURNETT (1958); $\mathbf{\Lambda} \mathbf{\Lambda}=$ results obtained in this work.

Corrélation entre la quantité du calcium ajoutée et l'inverse relative du temps de gélification. Le temps e gélification du lait sans calcium ajouté était pris pour une unité. - $\bullet$ = résultats de TARODO DE LA FUENTE et FRENTZ (1966); $\mathbf{m}$ = résultats de SCOTT-BLAIR et BURNETT (1958); $\mathbf{\Delta} \mathbf{\Delta}=$ résultats obterus dans ce travail.

Among the numerous physical, chemical and technological parameters which influence the rheological properties of rennet milk gels, $\mathrm{pH}$ and concentration of calcium ions were chosen because these two parameters play a key role in rennet coagulation of milk. There was linear correlation between $\mathrm{pH}$ of milk samples and relative reciprocal gelification time (fig. 12). Of course, theoretically, $\mathrm{pH}$ coagulation time dependence forms a Gauss type curve, but for a limited $\mathrm{pH}$ range it could be replaced by a hyperbolic relationship, as shown in the figure 12 . The gelification time ( $\mathrm{t}$ gel) at $\mathrm{pH} 6.6$ was taken as unity in order to be able to compare our results to those described in the literature. As shown in figure 12, gel is divided by 2 at $\mathrm{pH} 6.27$ and is twice longer at $\mathrm{pH}$ 6.75. These results are in good agreement with the data published by Fox (1969).

For quite a large range of added ionic calcium ions concentration $(0-15 \mathrm{mM})$ there was linear relationship between the relative reciprocal gelification time and the concentration of $\mathrm{Ca}$ ions (fig. 13). In this case the gelification time of milk with no calcium added was chosen for unity. To shorten twice the coagulation time at constant $\mathrm{pH}$, temperature and 


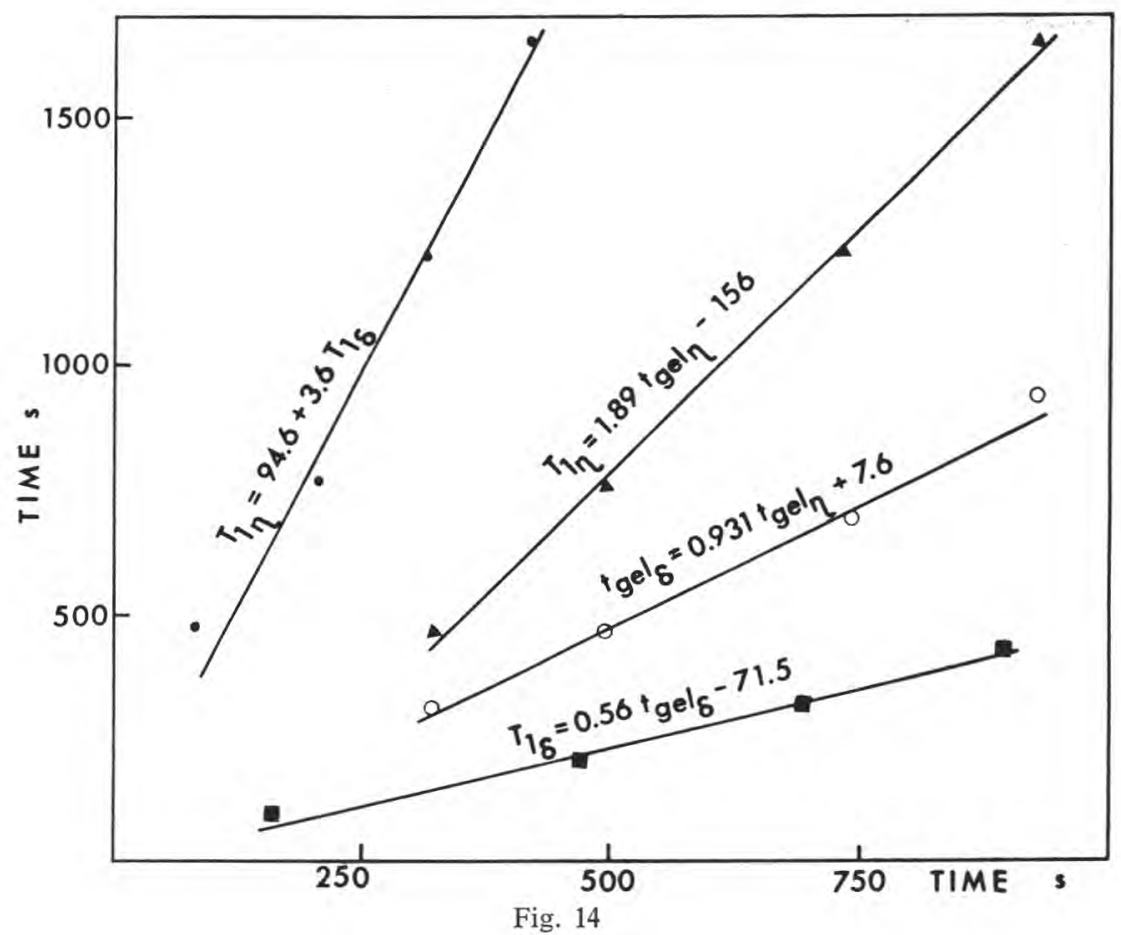

Relations between the gelification time and constant $T_{1}$ from the equation (4) calculated on the base of the results of evolution of viscosity or phase angle during rennet coagulation of milk.

Relations entre le temps de gélification et la constante $T_{I}$ de l'équation (4) calculée sur la base des résultats de l'évolution de la viscosité et de l'angle de déphasage pendant la coagulation du lait par la présure.

rennet/milk ratio, the addition of about $3.8 \mathrm{mM} \mathrm{Ca} / 1$ was required. The results obtained by other authors correspond well with ours (ScotT-BLAIR and Burnett, 1958 ; TARodo de LA Fuente and Frentz, 1966).

There were approximately linear relationships between the gelification time and $T_{1}$ calculated from the results representing the evolution of complex viscosity or phase angle (fig. 14). In average, the gelification time established from the phase angle changes is about $7 \%$ shorter than the one calculated from the results of viscosity. $\mathrm{T}_{1}$ estimated from phase angle evolution was about 4 times lower than the one calculated from viscosity evolution. This indicates that the evolution of phase angle is much faster than the evolution of viscosity. From this observation, it can be concluded that during rennet coagulation of milk, elasticity increase is faster and more important than the increase of viscosity.

Maximum complex viscosity estimated through equation (5) was about 1.3 Pas for the milk not enriched in calcium and 2.0 to 2.4 Pas for the milk added with $7.5 \mathrm{mM}$ of calcium ions. For the $\mathrm{pH}$ range 6.68-6.36, the 
maximum viscosity increased from 2 to 2.4 Pas with the decrease of $\mathrm{pH}$ level. Both effects show that free calcium ions play an important role in the formation of gel structure, what is already well known. The level of final viscosity of analyzed samples was in about the same range than the one observed by ToKITA and co-workers $(1980,1981,1982)$ and by BoHLIN et al. (1984).

It can be concluded that $\mathrm{pH}$ and calcium concentration influence strongly the gelification time, the rate of hardening of rennet milk gels and final level of aggregation of casein micelles. It seems that by using computerized dynamic rheometer it would be possible to estimate the importance of other physical, chemical and technological parameters of gelification of milk and maybe to establish the mathematical model of evolution of viscoelastic functions which would represent the whole process of rennet coagulation of milk better than other existing models.

\section{References}

BaChMan S., KLIMCZaK B., GaSyna Z., 1978. Non destructive viscometric studies of enzymic milk coagulation. I. An ultrasonic viscometric method for measurement of milk clotting activity of proteolytic enzymes. Acta Aliment. Pol., 4, (28), (1), 55-62.

Bachman S., KlimczaK B., Gasyna Z., 1980. Non destructive viscometric studies of enzymic milk coagulation. III. The effect of $\mathrm{pH}$, temperature and $\mathrm{Ca}$ ions concentration on the secondary phase of milk coagulation. Acta Aliment. Pol., 6, (30), (3), 135-143.

Bohlin L., Hegg P.O., LJubSERG-Wahren H., 1984. Viscoelastic properties of coagulating milk. J. Dairy Sci., 67, 729-734.

BURNETT J., SCotT-BLATR G.W., 1963. A speed compensated torsiometer for measuring the setting of milk by rennet. Dairy Ind., 28, 220-223.

Culioli J., Sherman P., 1978. Rheological aspects of the renneting of milk concentrated by ultrafiltration. J. Texture Stud., 9, 257-280.

DouILland R., 1973. Rheological analysis of curd formation. J. Texture Stud., 4, 158-165.

Fox P.F., 1969. Milk clotting and proteolytic activities rennet, and of bovine pepsin and porcine pepsin. J. Dairy Res., 36, 427-433.

GARNOT P., RANK T.C., OLSON N.F., 1982. Influence of protein and fat content of ultrafiltrated milk on rheological properties of gels formed by chymosin. J. Dairy Sci., 65, 2267-2273.

Gervals A., Vermeire D., 1983. A critical study and improvement of the cheese curd torsiometer. J. Texture Stud., 14, 31-45.

KorolczuK J., Roignant M., Maubois J.L., 1985. Computer data acquisition of sinusoidally varying stress and strain. J. Texture Stud., 16, 129-142.

KowalchYK W., OLSON N.F., 1978. Firmness of enzymatically formed milk gels measured by resistance to oscillatory deformation. J. Dairy Sci., 61, 1375-1379.

PARKER T.G., Dalgleish D.G., 1977 a. The potential application of the theory of branching processes to the association of milk protein. J. Dairy Res., 44, 79-84.

PaRKer T.G., DaLgleish D.G., 1977 b. The theory of branching processes applied to milk proteins. I. Heat-induced coagulation of whole milk. J. Dairy Res., 44, 85-92.

Qvist K.B., 1982. A mathematical description of the coagulation of milk with rennet, when measuring with the formagraph. Proc. XXI Int. Dairy Cong., 1, (2), 238-239.

RAmet J.P., El Mayada E., Weber F., 1982. Nouvelle méthode continue pour la mesure objective de la rigidité des gels lactés. Lait, 62, 511-520. 
SCOtt-Blair G., Burnett J., 1958 a. Physical changes in milk caused by the action of rennet. Description of apparatus for measuring rigidity moduli and internal viscosities, tests of reliability and some observations on syneresis. J. Dairy Res., 25, 297-303.

SCOTt-Blatr G., Burnett J., 1958 b. Physical changes in milk caused by the action of rennet. III. Effects of separation, homogenization and pasteurization and of varying calcium content on the rigidity moduli and viscosities of curd. J. Dairy Res., 25, 457-466.

Scott-Blatr G., Burnett J., 1959. Physical changes in milk caused by the action of rennet. IV. Effects of varying rennet concentration and temperature. J. Dairy Res., 26, 58-62.

SCOTT-Blair G., BuRnetT J., 1963. An equation to describe the rate of setting of blood and milk. Biorheol., 1, 183-191.

Scott-Blair G., Burnett J., 1963. A simple method for detecting an early stage in coagulation of rennetted milk. J. Dairy Res., 30, 383-390.

Scott-Blair G., Oosthuizen J.C., 1961. A viscometric study of the breakdown of casein in milk by rennin and rennet. J. Dairy Res., 28, 165-173.

Tarodo de la Fuente B., Alais C., Frentz, 1969. Etude de la coagulation du lait par la présure et de la synérèse du coagulum par la méthode thromboélastographique. Lait, $49,400-416$.

TARodo de la Fuente B., Frentz R., 1966, Etude thromboélastographique de la coagulation du lait par la présure : action de la température et de la concentration en calcium. Lait, 46, 371-392.

Tokita M., Futakuchi H., Hikichi K., Niki R., ARima S., 1982 a. Dynamic mechanical properties of milk and milk gel. Rep. Prog. Polym. Phys. Jpn, 25, 823-824.

Tокita M., Hikichi K., Niki R., ARIMA S., 1980. Dynamic viscoelastic study on the formation of casein networks in milk-rennet systems. Rep. Prog. Polym. Phys. Jpn, 23, 729-730.

Tokita M., Hikichi K., Niki R., ARima S., 1981. Mechanism of milk clotting. Rep. Prog. Polym. Phys. Jpn, 24, 581-584.

TокIтA M., HткIснI K, NIKI R., ARIMA S., 1982 b. Mechanism of enzymatic clotting process on casein micelle solution. Rep. Prog. Polym. Phys. Jpn, 25, 825-828.

Tokita M., Hikichi K., NiKi R., ARIMA S., 1982. Dynamic viscoelastic studies on the mechanism of milk clotting process. Biorheol., 19, 209-219.

Tsouli J., Favre-Bonvin G., Policard C., Ville A., 1975. Mesure par la méthode conductimétrique de l'activité enzymatique de trois variétés de présure sur du lait frais de mélange et du lait reconstitué à partir de poudre dégraissée. Lait, 55, 289-294.

TUSZYNSKI W., 1971. A kinetic model of the clotting of casein rennet. J. Dairy Res., 38, $115-125$.

Tuszynski A., Burnett J., ScotT-Blair G.W., 1968. The effects of variations in pH, of removal of calcium and of the addition of sulphur-bond inhibitors on the rate of setting of renneted milk. J. Dairy Res., 35, 71-83. 